\title{
Epidemiological profile and pain degree in women who inserted intrauterine device
}

\author{
Perfil epidemiológico e grau de dor em mulheres que inseriram dispositivo intrauterino \\ Perfil epidemiológico y grado de dolor en mujeres que insertaron dispositivo intrauterino
}

Received: 08/31/2021 | Reviewed: 09/09/2021 | Accept: 09/11/2021 | Published: 09/13/2021

\author{
Adriellen Pinto Carvalho \\ ORCID: https://orcid.org/0000-0002-9654-6539 \\ Universidade Federal de Sergipe, Brazil \\ E-mail: adriellenpinto@gmail.com \\ João Eduardo Andrade Tavares de Aguiar \\ ORCID: https://orcid.org/0000-0002-9576-8148 \\ Universidade Federal de Sergipe, Brazil \\ E-mail: joaoeduardoandrade97@gmail.com.br \\ Marcos Antônio Lima Carvalho \\ ORCID: https://orcid.org/0000-0002-3543-2028 \\ Universidade Federal de Sergipe, Brazil \\ E-mail: marcoslimac27@gmail.com \\ Ullany Maria Lima Amorim Coelho de Albuquerque \\ ORCID: https://orcid.org/0000-0002-8243-8369 \\ Universidade Federal de Sergipe, Brazil \\ E-mail: ullanylima@gmail.com \\ Vinícius da Silva Martins \\ ORCID: https://orcid.org/0000-0002-6673-8003 \\ Universidade Federal de Sergipe, Brazil \\ E-mail: martinsvinicius51@gmail.com \\ Laís Baldin \\ ORCID: https://orcid.org/0000-0002-2691-3356 \\ Universidade Federal de Sergipe, Brazil \\ E-mail: lais.baldin003@gmail.com \\ Mariana Fontes Andrade Almeida \\ ORCID: https://orcid.org/0000-0002-0261-0852 \\ Universidade Federal de Sergipe, Brazil \\ E-mail: marianafontesaa@ outlook.com \\ Bárbara Rhayane Santos \\ ORCID: https://orcid.org/0000-0002-4981-2777 \\ Universidade Federal de Sergipe, Brazil \\ E-mail: barbara.rhayane@gmail.com \\ Marco Antônio Prado Nunes \\ ORCID: https://orcid.org/0000-0001-5244-5843 \\ Universidade Federal de Sergipe, Brazil \\ E-mail: nunes.ma@ufs.br \\ Francisco de Assis Pereira \\ ORCID: https://orcid.org/0000-0002-8464-6188 \\ Universidade Federal de Sergipe, Brazil \\ E-mail: fraspe@bol.com.br \\ Daniela Siqueira Prado \\ ORCID: https://orcid.org/0000-0002-3901-3832 \\ Universidade Federal de Sergipe, Brazil \\ E-mail: danisprado77@gmail.com \\ Júlia Maria Gonçalves Dias \\ ORCID: https://orcid.org/0000-0001-9145-5534 \\ Universidade Federal de Sergipe, Brazil \\ E-mail: dias_jmg@yahoo.com.br \\ Thaís Serafim Leite de Barros Silva \\ ORCID: https://orcid.org/0000-0003-1696-6507 \\ Universidade Federal de Sergipe, Brazil \\ E-mail: thaisserafim@hotmail.com
}

\begin{abstract}
The intrauterine device (IUD) is a long-acting reversible contraceptive (LARC) option and has a low cost to the health system. It is an excellent cost-effective strategy for contraception. This study aimed to characterize the epidemiological profile of women who had an IUD inserted, in addition to evaluating the degree of pain during insertion, correlating it with age and obstetric variables. This is a retrospective study with women who inserted an
\end{abstract}


IUD in a reference service in Sergipe between November 2018 and February 2021. Information such as age, number of pregnancies, deliveries and abortions before IUD insertion, pathology or reason for IUD indication, pain scale, hysterometry and wire size after insertion was analyzed. The study included 346 women who inserted copper IUDs and 47 who inserted hormonal IUDs. The mean age of patients was 27.1 years and 33.7 years, mean pain was 4.6 and 5.5 and mean hysterometry was 8.29 and 8.55 , respectively. It was noticed that more than $60 \%$ of women had at least one pregnancy prior to insertion of the device, in both cases. There was no correlation between pain level and age and parity. Most women who inserted IUDs were in the post-adolescent phase. In addition, most had already had at least one previous pregnancy and experienced moderate pain during IUD insertion.

Keywords: Intrauterine devices; Long-acting reversible contraception; Hormonal contraception.

\section{Resumo}

O dispositivo intrauterino (DIU) é uma opção de contraceptivo reversível de longa duração (LARC) e possuem baixo custo para o sistema de saúde, sendo, portanto, uma ótima estratégia custo-efetiva para anticoncepção. O objetivo foi caracterizar o perfil epidemiológico das mulheres que inseriram DIU, além de avaliar o grau de dor na inserção, correlacionando-o com idade e variáveis obstétricas. Trata-se de um estudo retrospectivo com mulheres que inseriram DIU em um serviço de referência em Sergipe entre novembro de 2018 e fevereiro de 2021. Foram analisadas informações como idade, quantidade de gestações, partos e abortos antes da inserção do DIU, patologia ou motivo da indicação do DIU, escala de dor, histerometria e tamanho do fio após inserção. 346 mulheres inseriram DIU de cobre e 47 inseriram DIU hormonal. A média de idade das pacientes foi de 27,1 anos e 33,7 anos, a média de dor foi 4,6 e 5,5 e a média de histerometria foi de 8,29 e 8,55, respectivamente. Percebeu-se que mais de $60 \%$ das mulheres, tinham pelo menos uma gestação anterior à inserção do dispositivo, em ambos os casos. Não existiu correlação entre nível de dor e idade e paridade. A maioria das mulheres que inseriram DIU encontravam-se em fase após adolescência. Além disso, a maior parte já tinha tido pelo menos uma gestação prévia e apresentou dor moderada durante a inserção do DIU.

Palavras-chave: Dispositivos intrauterinos; Contracepção reversível de longo prazo; Contracepção hormonal.

\section{Resumen}

El dispositivo intrauterino (DIU) es una opción anticonceptiva reversible de acción prolongada (LARC) y tiene un bajo costo para el sistema de salud, por lo tanto, es una excelente estrategia costo-efectiva para la anticoncepción. El objetivo fue caracterizar el perfil epidemiológico de las mujeres a las que se les colocó un DIU, además de evaluar el grado de dolor durante la inserción, correlacionándolo con edad y variables obstétricas. Se trata de un estudio retrospectivo con mujeres que se colocaron un DIU en un servicio de referencia en Sergipe entre noviembre de 2018 y febrero de 2021. Se analizó información como edad, número de embarazos, partos y abortos antes de la inserción del DIU, patología o motivo de la indicación del DIU, escala de dolor, histerometría y tamaño del alambre después de la inserción. 346 mujeres se colocaron DIU de cobre y 47 se colocaron DIU hormonales. La edad media de los pacientes fue 27,1 años y 33,7 años, el dolor medio fue 4,6 y 5,5 y la histerometría media fue 8,29 y 8,55, respectivamente. Se notó que más del $60 \%$ de las mujeres tenían al menos un embarazo antes de la inserción del dispositivo, en ambos casos. No hubo correlación entre el nivel de dolor y la edad y la paridad. La mayoría de las mujeres que se colocaron DIU estaban en la fase posadolescente. Además, la mayoría ya había tenido al menos un embarazo anterior y experimentaron un dolor moderado durante la inserción del DIU.

Palabras clave: Dispositivos intrauterinos; Anticoncepción reversible de larga duración; Anticoncepción hormonal.

\section{Introduction}

Gestational planning has evolved along with the evolution of knowledge about the physiology of reproduction. Many effective forms of contraception were created when it became possible to determine the menstrual cycle, isolate hormones and their receptors, and understand reproduction anatomically (Holanda et al., 2013).

Contraceptive methods are issues that are within public health issues through Federal Law No. 9,203/96, which advocates that all citizens have the right to carry out family planning. Through it, it was possible to implement, in 2004, the National Policy for Comprehensive Care for Women's Health (Holanda et al., 2013). However, reproductive planning is still a challenge in Brazil (Barreto et al., 2021).

Long-term contraception aims to plan the number of members who will form the family, schedule the best time for pregnancy, prevent risky pregnancies and help control unwanted teenage pregnancies. In addition, some methods have additional benefits and can contribute to the treatment of some clinical conditions (Penna \& Brito, 2015).

The intrauterine device (IUD) is a long-acting reversible contraceptive (LARCs) option and has a low cost to the 
health system, therefore, it is an excellent cost-effective strategy for contraception. In addition, the IUD has a failure rate of between $0.6-08 \%$ in the first year, being more effective than other methods such as pills or patches (Barreto et al., 2021; Morais et al., 2021).

In the Unified Health System (SUS), copper IUD is offered, which causes a local inflammatory reaction and, consequently, hinders embryonic implantation and sperm capacitation. In addition to this IUD, there is also the Levonogestrel IUD (LNG-IUD), which causes an atrophy of the endometrium, altering the quality of the cervical mucus. This makes it difficult for sperm to ascend to the fallopian tubes (Morais et al., 2021; Neris et al., 2021).

Despite being a cost-effective contraceptive option, this method is still underutilized in Brazil (Morais et al., 2021). The main reason for this is lack of information. Some women believe that it requires a surgical procedure for insertion, in addition to causing infertility and a change in sexual practice (Ferreira et al., 2020). Another justification is the patients' anxiety related to the pain caused by the insertion of the IUD (Miranda et al., 2018).

Thus, the present study aimed to characterize the epidemiological profile of women who inserted an IUD in a reference service in Sergipe, in addition to evaluating the degree of pain at insertion, correlating it with age and obstetric variables.

\section{Methodology}

This is a retrospective cross-sectional study with women who had an IUD inserted at the University Hospital of the Federal University of Sergipe (HU-UFS) (Pereira et al., 2018). The sample consisted of 393 patients, 346 of whom inserted copper IUD (Cu-IUD) and 47 inserted Levonogestrel hormonal IUD (LNG-IUD) at the University Hospital of the Federal University of Sergipe between November 2018 and February 2021.

All women who had an IUD inserted at the HU-UFS outpatient clinic were included in the study. Patients who refused to participate in the study or who underwent IUD insertion using sedation were excluded from the study.

Data from annotations in the IUD insertions registry book, filled out exclusively by the physicians responsible for the service, residents and medical interns, were used. Information such as age, number of pregnancies, deliveries and abortions before insertion of the IUD, pathology or reason for the indication of the IUD, pain scale, hysterometry and wire size after insertion were analyzed.

All study participants used anti-inflammatory drugs at least 30 minutes before the procedure. In addition, it was mandatory, before insertion of the device, the presentation of a negative pregnancy test for all and a cytopathological examination of the uterus only for women over 25 years of age.

In relation to obtaining pain scale values, patients were offered a visual analogue pain scale so they could identify their level of pain during the procedure, with mild pain being considered as pain with values from zero to two, moderate pain with values from three to seven, and severe pain from eight to ten.

An Informed Consent Form was given to the patients, which was signed in duplicate, one being held by the interviewer and the other by the patient.

To perform the analysis, the variables were tabulated in an Excel spreadsheet, and the correlation between the variables pain scale and age, pregnancies, deliveries and abortions was performed using the Pearson correlation coefficient. After that, graphs and tables were made with the interpretation of the results.

The planning of this research was carried out in accordance with the Declaration of Helsinki and Resolution 466, of 2012, of the National Health Council. The project was submitted to the Research Ethics Committee of the Federal University of Sergipe, being approved under CAAE: 15885719.5.0000.5546. 


\section{Results}

The present study evaluated 393 patients who inserted the device between November 2018 and February 2021, divided into two categories: the category of Cu-IUD users, consisting of 346 women, and the category of LNG-IUD users, consisting of 47 patients.

Regarding the age of the patients, it was noticed that the average age of IUD-Cu users was 27.1 years, with a minimum of 13 years and a maximum of 46 years. Among LNG-IUD users, the mean age was 33.7 years, with a minimum of 18 years and a maximum of 49 years (Table 1$)$.

Table 1. Age variable among users of the intrauterine device at the University Hospital of the Federal University of Sergipe.

\begin{tabular}{cccc}
\hline & COPPER IUD & & \multicolumn{2}{c}{ LEVONORGESTREL-RELEASING IUD } \\
\hline Average age & 27.1 & Average age & 33.7 \\
Minimum & 13 & Minimum & 18 \\
Maximum & 46 & Maximum & 49 \\
Median & 26 & Median & 33 \\
Mode & 23 & Mode & 26 \\
\hline
\end{tabular}

IUD: intrauterine device. Source: Authors.

Referring to the pain scale, $47(13.6 \%)$ of the $\mathrm{Cu}$-IUD users had severe pain, $220(63.6 \%)$ moderate pain and 79 $(22.8 \%)$ mild pain (Graphic 1). In addition, mean pain in this group was 4.6, with minimum 0 and maximum 10. Among LNGIUD users, mean pain was 5.5, with minimum 0 and maximum 10 (Table 2).

Graphic 1. Counting the pain scale in users of the copper intrauterine device at the University Hospital of Sergipe.

\section{Counting the pain scale}

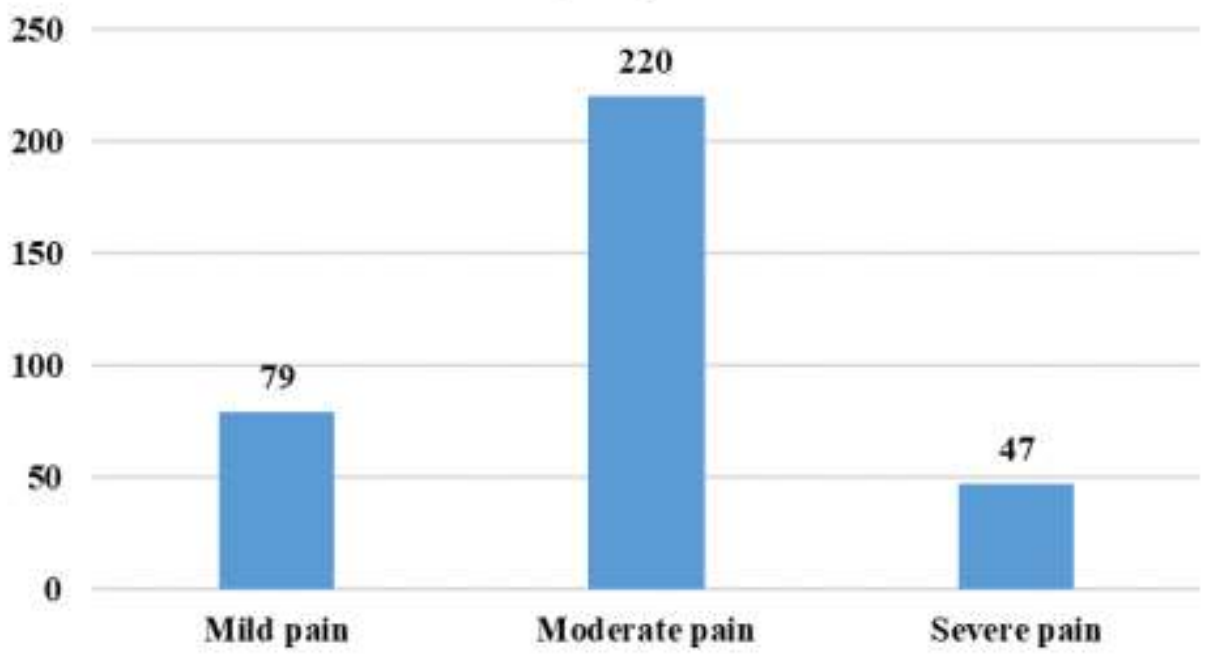

Source: Authors. 
Table 2. Scale of pain during insertion of the intrauterine device among users of the University Hospital of the Federal University of Sergipe.

\begin{tabular}{cccc}
\hline & COPPER IUD & & \multicolumn{2}{c}{ LEVONORGESTREL-RELEASING IUD } \\
\hline Average & 4.6 & Average & 5.55 \\
Minimum & 0 & Minimum & 0 \\
Maximum & 10 & Maximum & 10 \\
Median & 5 & Median & 6 \\
Mode & 5 & Mode & 6 \\
\hline
\end{tabular}

IUD: intrauterine device. Source: Authors.

Data referring to number of pregnancies, deliveries and abortions of patients before insertion of the IUD were also analyzed. Regarding the $\mathrm{Cu}-\mathrm{IUD}$, the average of pregnancies was 1.24 , with a minimum of 0 and a maximum of 6 . The average of deliveries in this group was 1 , with a minimum of 0 and a maximum of 5 , and the average of abortions was 0.22 , with a minimum of 0 and a maximum of 4 . As for the LNG-IUD, the average of pregnancies was 1.4 , with the minimum of 0 and the maximum of 5 , the average of deliveries was 1.1 , with a minimum of 0 and a maximum of 3 , and the mean of abortions was 0.3 , with a minimum of 0 and a maximum of 2 (Table 3 ).

Table 3. Analysis of pregnancies, deliveries and abortions among users of the intrauterine device at the University Hospital of the Federal University of Sergipe.

\begin{tabular}{|c|c|c|c|}
\hline \multicolumn{2}{|c|}{ COPPER IUD } & \multicolumn{2}{|c|}{ LEVONORGESTREL-RELEASING IUD } \\
\hline \multicolumn{4}{|c|}{ PREGNANCIES } \\
\hline Average & 1.24 & Average & 1.4 \\
\hline Minimum & 0 & Minimum & 0 \\
\hline Maximum & 6 & Maximum & 5 \\
\hline Median & 1 & Median & 1 \\
\hline Mode & 1 & Mode & 0 \\
\hline \multicolumn{4}{|c|}{ DELIVERIES } \\
\hline Average & 1.02 & Average & 1.1 \\
\hline Minimum & 0 & Minimum & 0 \\
\hline Maximum & 5 & Maximum & 3 \\
\hline Median & 1 & Median & 1 \\
\hline Mode & 1 & Mode & 0 \\
\hline \multicolumn{4}{|c|}{ ABORTIONS } \\
\hline Average & 0.22 & Average & 0.3 \\
\hline Minimum & 0 & Minimum & 0 \\
\hline Maximum & 4 & Maximum & 2 \\
\hline Median & 0 & Median & 0 \\
\hline Mode & 0 & Mode & 0 \\
\hline
\end{tabular}

IUD: intrauterine device. Source: Authors.

Of the 346 women in the first category (Cu-IUD), $111(32.1 \%)$ were nulliparous and $235(67.9 \%)$ had presented at 
least one pregnancy. While in the second category (LNG-IUD), of the 47 patients, 17 were nulliparous (36.2\%) and 30 (63.8\%) had at least one pregnancy.

We also analyzed the main indications for insertion of the LNG-IUD, which were shown in Table 4. The indication of the $\mathrm{Cu}$-IUD is only contraception. However, the comorbidities of patients who inserted this type of IUD were evaluated (Table $5)$.

Table 4. Main pathologies or indications for insertion of the hormonal intrauterine device among users of the University Hospital of the Federal University of Sergipe.

\begin{tabular}{lc}
\hline \multicolumn{2}{c}{ LEVONORGESTREL-RELEASING IUD } \\
\hline Pathology/indication & $\mathbf{n}(\%)$ \\
\hline Contraception & $4(8.51)$ \\
Type 1 Diabetes Mellitus & $1(2.13)$ \\
Migraine & $1(2.13)$ \\
Abnormal Uterine Bleeding & $22(46.81)$ \\
Adenomyosis/endometriosis & $17(36.17)$ \\
Bariatric surgery & $1(2.13)$ \\
Uterine fibroids & $1(2.13)$ \\
\hline
\end{tabular}

IUD: intrauterine device. Source: Authors.

Table 5. Comorbidities of users of the copper intrauterine device at the University Hospital of the Federal University of Sergipe.

\begin{tabular}{cc}
\hline & COPPER IUD \\
\hline Comorbidities & $\mathbf{n}(\boldsymbol{\%})$ \\
\hline Type 1 Diabetes Mellitus & $1(0.29)$ \\
Migraine & $5(1.44)$ \\
Abnormal Uterine Bleeding/Deep Venous Thrombosis & $2(0.58)$ \\
Asthma & $1(0.29)$ \\
Dermatomyositis & $1(0.29)$ \\
Hypothyroidism & $1(0.29)$ \\
Hansen's disease & $2(0.58)$ \\
Systemic Arterial Hypertension & $2(0.58)$ \\
Lymphangiomyomatosis & $1(0.29)$ \\
Systemic lupus erythematosus & $4(1.16)$ \\
Thrombophilia & $1(0.29)$ \\
No comorbidities & $325(93.92)$ \\
\hline
\end{tabular}

IUD: intrauterine device. Source: Authors.

When analyzing the hysterometry data of the Cu-IUD users, it was noted that the mean of the hysterometry was 8.29, with a minimum of 6 and a maximum of 20. The mean of the hysterometry of the LNG-IUD was 8.55, with a minimum of 6 and a maximum of 12 .

When analyzing the correlations between the variables and the pain scale of IUD-Cu users, it was observed that, between age and scale and pain, the Pearson coefficient value was -0.04 . Between pregnancy and pain scale, the value obtained 
was -0.2 ; between delivery and pain scale, it was found -0.22 ; and, between abortion and pain scale, it was -0.05 . All these values showed that there is no correlation between the variables, as values close to zero were obtained.

Regarding the LNG-IUD, the correlation between the pain scale and age had a value of -0.2 ; between pain scale and pregnancy, the value presented was -0.21 ; between pain scale and delivery was -0.23 ; and, between pain scale and abortion, it was -0.1 . These values also showed that there is no correlation between the variables.

\section{Discussion}

150 million women around the world use the IUD. It is the most common form of reversible contraception in the world, with a negligible failure rate, and it can be used for a long period. Nowadays, it is more common in developing countries and, after surgical sterilization; it is the main method of family planning (Holanda et al., 2013; Leão et al., 2021).

In the present study, 393 women were interviewed, 346 of whom attended for insertion of the $\mathrm{Cu}$-IUD and 47 for insertion of the LNG-IUD. This percentage is not due to the choice of the patient, but to the availability of the service. At the HU-UFS, regulated by SUS, only the Cu-IUD is available. Obtaining LNG-IUD was made possible by a training action for physicians and residents. This is also verified in other services (Gonzaga et al., 2017).

Despite the recommendation to indicate LARCs to adolescents, only 19 (5.4\%) of the women were at this stage of life. Value close to the study carried out in Recife, with only $15.5 \%$ of users (Campos et al., 2020). This information is quite worrying due to the small number of adolescents seeking some contraceptive method, and this concern is reinforced by Vieira et al. (2006) when analyzing the fertility rates in the national territory, in which the number of pregnancies decreased in all age groups, except in adolescence, especially between 15 and 19 years old.

Among the causes for not using contraceptive methods among adolescents, there is a lack of conversation with the sexual partner and little information about contraceptive methods and reproduction. In addition, other causes of teenage pregnancy are mentioned, such as social aspects, lack of access to certain services for that age, early sexual life and lack of security in using contraceptive methods (Vieira et al., 2006).

In this study, when evaluating the age variable, a similarity was evidenced between the average age of insertion of the $\mathrm{Cu}-\mathrm{IUD}$ and the LNG-IUD. The reproductive age is considered between 15 and 44 years, a period considered ideal for the use of contraceptive methods (Brasil, 2004).

It was noticed that only $13.6 \%$ of patients had severe pain during device insertion. Average pain was 4.6 for the $\mathrm{Cu}$ IUD and 5.5 for the LNG-IUD. This small number of women who presented severe pain in the study is very positive and significant, since, according to data from Lopez et al. (2015), intense pain is one of the factors that make women give up on insertion and use of the device. In addition, the location of the procedure, the clinician's confidence and technique, and the doctor-patient relationship can positively or negatively impact a woman's anxiety level and influence her perception of pain (Bahamondes et al., 2014).

Regarding obstetric variables (pregnancy, childbirth and abortion), there was no difference between parity and the type of IUD inserted. It is noteworthy that, although most participants have had at least one pregnancy, there is still a very big obstacle in relation to the intrauterine contraceptive method in nulliparous women, as many believe that it is only after childbirth that the IUD can be used. Another reason is the fact that many professionals have doubts about the use of this device in nulliparous women and about the risks of pelvic inflammatory disease, infertility and barriers to insertion (Machado, 2017).

In this study, the main indication for IUD insertion can be evaluated. In the case of the Cu-IUD, the indication was contraception, as it is its only indication (Slywitch et al., 2021). One patient returned to the clinic for replacement. The Cu-IUD is indicated for women who want to obtain a reversible and long-lasting contraceptive method. It has no contraindications, and can also be used by nursing mothers or women who cannot use estrogen, who have a low risk of contracting sexually 
transmitted diseases and who do not want to use hormones as a form of contraception (Giordano, Giordano \& Panisset, 2015).

As for the LNG-IUD, the main pathology/indication was abnormal uterine bleeding (AUB) (46.8\%). Hormonal IUD is an alternative for the treatment of hemorrhage, endometrial hyperplasia and adenomyosis, in addition to improving symptoms and regulating the menstrual pattern of patients with endometriosis (Slywitch et al., 2021). Thus, this IUD can be used as a way to prevent pregnancy, in cases of endometriosis, large menstrual bleeding for no organic reason and protection against endometrial hyperplasia (Monteiro, 2015). Through these data, it appears that the literature data, in relation to the main references of the use of the IUD, corroborate the data collected at the HU-UFS.

In order to insert the IUD, hysterometry must be performed carefully so that the depth and angle of the uterus can be determined. This reduces the chance of uterine perforation, which can happen if the hysterometer or the IUD is inserted too deeply, or at the wrong angle (Brasil, 2018). Thus, it was noticed that the mean hysterometry among the Cu-IUD users was 8.29 and the LNG-IUD was 8.55. Ideally, a hysterometry between 6 and $9 \mathrm{~cm}$ is found so that the procedure continues to be performed with greater safety, which was seen in the averages of the patients at the HU-UFS (Brasil, 2018).

In the present study, no correlation was found between age and the pain scale, as well as between the number of pregnancies, births and abortions and the pain scale. It was also observed that in the literature there is a lack of data regarding these correlations.

\section{Conclusion}

Most women who inserted an IUD were in the post-adolescent phase, with an average age of $27.1 \mathrm{for}$ the $\mathrm{Cu}$-IUD and 33.7 for the LNG-IUD. In addition, for both groups, most had already had at least one previous pregnancy and experienced moderate pain during IUD insertion. There was no association between pain and age and obstetric variables.

It is necessary to monitor these women in subsequent consultations to obtain more information about them and about the continued use of the device, making it possible, in this way, to analyze more variables and make more data available so that they can be useful in the adoption of policies and actions that improve the sexual and reproductive planning of these and other women.

\section{References}

Bahamondes, L., Mansour, D., Fiala, C., Kaunitz, A. M. \& Gemzell-Danielsson, K. (2014). Practical advice for avoidance of pain associated with insertion of intrauterine contraceptives. The Journal of Family Planning and Reproductive Health Care, 40(1), 54-60. https://doi.org/10.1136/jfprhc-2013-100636

Barreto, D. da S., Maia, D. S., Gonçalves, R. D. \& Soares, R. de S. (2021). Dispositivo Intrauterino na Atenção Primária a Saúde: uma revisão integrativa. Revista Brasileira de Medicina de Família e Comunidade, 16(43), 2821. https://doi.org/10.5712/rbmfc16(43)2821

Brasil. Ministério da Saúde. Secretaria de Vigilância em Saúde. Departamento de Análise de Situação de Saúde. (2004). Saúde Brasil 2004 - uma análise da situação de saúde / Ministério da Saúde, Secretaria de Vigilância em Saúde, Departamento de Análise de Situação de Saúde. - Brasília: Ministério da Saúde, 2004. https://bvsms.saude.gov.br/bvs/publicacoes/saude_brasil_2004.pdf

Brasil. Ministério da Saúde. Secretaria de Atenção à Saúde. Departamento de Ações Programáticas Estratégicas. (2018). Manual técnico para profissionais de saúde-DIU com cobre TCu 380A / Ministério da Saúde, Secretaria de Atenção à Saúde. Departamento de Ações Programáticas Estratégicas. - Brasília: Ministério da Saúde, 2018. https://portaldeboaspraticas.iff.fiocruz.br/biblioteca/manual-tecnico-para-profissionais-de-saude-diu-com-cobre-tcu-380a/

Campos, L. F. de S., Carvalho, M. L. P., Lima, R. N. C. L., Lima, D. L., Brito, R. de C. C. M. de \& Leal Júnior, C. C. (2020). Avaliação da satisfação das usuárias do dispositivo intrauterino T CU 380A acompanhadas no ambulatório de planejamento familiar em um hospital escola de Recife, Pernambuco. Revista de Medicina, 99(6), 538-544. https://doi.org/10.11606/issn.1679-9836.v99i6p538-544

Ferreira, A. A., Roza, A. D. S., Neves, I. H. Q. \& Argentina, C. I. M. (2020). Rejeição ao uso do dispositivo intra-uterino (DIU) como método contraceptivo em mulheres em idade reprodutiva. Anais do fórum de iniciação científica do UNIFUNEC, 9(9). https://seer.unifunec.edu.br/index.php/forum/article/view/3864

Giordano, M. V., Giordano, L. A. \& Panisset, K. S. (2021). Dispositivo intrauterino de cobre. FEMINA, 43(suppl. 1). http:/files.bvs.br/upload/S/01007254/2015/v43nsupp11/a4850.pdf 
Gonzaga, V. A. S., Borges, A. L. V., Santos, O. A. dos, Rosa, P. L. F. S. \& Gonçalves, R. F. S. (2017). Barreiras organizacionais para disponibilização e inserção do dispositivo intrauterino nos serviços de atenção básica à saúde. Revista da Escola de Enfermagem da USP, 51. https://doi.org/10.1590/S1980220X2016046803270

Holanda, A. A. R. de, Barreto, C. F. B., Holanda, J. de C. P., Mota, K. B., Medeiros, R. D. de \& Maranhão, T. M. de O. (2013). Controvérsias acerca do dispositivo intrauterino: uma revisão. FEMINA, 41(3), 141-146. http://files.bvs.br/upload/S/0100-7254/2013/v41n3/a3812.pdf

Leão, J. P. P., Orsi, I. M. E., Leão, A. S., Orsi, T. D., Leão, D. M. P. \& Orsi, P. M. E. (2021). Sistema intrauterino em localização extrauterina. Research, Society and Development, 10(5). http://dx.doi.org/10.33448/rsd-v10i5.14585

Lopez, L. M., Bernholc, A., Zeng, Y., Allen, R. H., Bartz, D., O'Brien, P. A. \& Hubacher, D. (2015). Interventions for pain with intrauterine device insertion. The Cochrane database of systematic reviews, (7), CD007373. https://doi.org/10.1002/14651858.CD007373.pub3

Machado, R. B. (2017). Uso de dispositivos intrauterinos (DIU) em nuliparas. São Paulo: Federação Brasileira das Associações de Ginecologia e Obstetrícia (FEBRASGO). (Série de Orientações e Recomendações FEBRASGO, no. 1/Comissão Nacional Especializada em Anticoncepção).

Miranda, A., Almendra, R., Feliciano, E., Ricardo, C., Nápoles, S. \& Nogueira-Silva, C. (2018). Fatores associados à perceção de ansiedade e dor na colocação do Sistema Intrauterino com Levonorgestrel. Acta Obstetrica e Ginecologica Portuguesa, 12(4), 268-276. http://www.fspog.com/fotos/editor2/06eo_18-00005.pdf

Monteiro, I. M. U. (2015). Contracepção de longo prazo: dispositivo intrauterino (Mirena). FEMINA, 43(suppl. 1). http://files.bvs.br/upload/S/01007254/2015/v43nsupp11/a4851.pdf

Morais, I. G. de F., Barreto, D. da S., Melo Neto, A. J. de, Soares, R. de S., Gonçalves, R. D., Rêgo, M. E. de M. P. do \& Costa, P. S. R. (2021). Perfil das mulheres submetidas à inserção do dispositivo intrauterino de cobre na Atenção Primária à Saúde de municípios da Paraíba. Revista Brasileira de Medicina de Família e Comunidade, 16(43), 2649. https://doi.org/10.5712/rbmfc16(43)2649

Neris, V. S., Rates, M. L. S. R., Nunes, M. A. P., Pereira, F. de A., Dias, J. M. G. \& Silva, T. S. L. de B. (2021). Nível de conhecimento dos estudantes de medicina sobre dispositivos intrauterinos na Universidade Federal de Sergipe. Brazilian Journal of Health Review, 4(1), 2289-2302. https://doi.org/10.34119/bjhrv4n1-185

Penna, I. A. de A. \& Brito, M. B. (2015). A importância da contracepção de longo prazo reversível. FEMINA, 43(suppl. 1). http://files.bvs.br/upload/S/01007254/2015/v43nsuppl1/a4848.pdf

Pereira, A. S., Shitsuka, D. M., Parreira, F. J. \& Shitsuka, R. (2018). Metodologia da pesquisa científica. UFSM.

Slywitch, N. C., Alves, B. P., Martins, E. A. de P., Romão, J. V., Amorim, M. S., Vilela, M. P.-D., Borges, M. S., Borges, N. L. G., Cunha Neto, V. F. da \& Novais, D. F. F. (2021). Comparação entre os dispositivos intrauterinos de cobre e hormonal: uma revisão narrativa. Revista Eletrônica Acervo Saúde, 13(5), e7345. https://doi.org/10.25248/reas.e7345.2021

Vieira, L. M., Saes, S. de O., Dória, A. A. B. \& Goldberg, T. B. L. (2006). Reflexões sobre a anticoncepção na adolescência no Brasil. Revista Brasileira de Saúde Materno Infantil, 6(1), 135-140. https://doi.org/10.1590/S1519-38292006000100016 